\title{
Effects of Bee Propolis on Blood Pressure Record and Certain Biochemical Parameter in Healthy Volunteers
}

\author{
Dhamyaa A. Khalaf, Imad A-J Thanoon \\ Department of Pharmacology, College of Medicine, University of Mosul, Mosul, Iraq. \\ Correspondence: Dhamyaa A. Khalaf. dhamyaaahmed@yahoo.com.
}

(Ann Coll Med Mosul 2018; 40 (1): 20-26).

Received: $20^{\text {th }}$ Apr. 2018; Accepted: $11^{\text {th }}$ Jun. 2018.

\section{ABSTRACT}

Objectives: To evaluate the effect of encapsulated bee propolis supplementation $500 \mathrm{mg}$ twice daily for 2 months on blood pressure record, fasting serum glucose, lipid profile and serum uric acid in otherwise healthy volunteers in comparison to controls.

Design: The study was conducted from October 2017 to April 2018, subjects included in the study was healthy non-obese from different areas in Mosul city, so as the control.

Subjects and methods: Forty apparently healthy subjects (Sixteen male and twenty-four female) were included in this study. Blood pressure (BP) were recorded, body weight and body mass index (BMI) were calculated, then a blood sample was taken with assay of fasting serum glucose (FSG), lipid profile \{Total cholesterol (TC), triglyceride (TG), high density lipoprotein (HDL $-C$ ), while serum low density lipoprotein $(\mathrm{LDL}-\mathrm{C})$, very low density lipoprotein (VLDL-C) and atherogenic index (AI)\} were calculated by using certain equations and serum uric acid (SUA), was measured for both the intervention and the control groups.

After 2 months of supplementation with encapsulated bee propolis $500 \mathrm{mg}$ twice daily, the BP, body weight, BMI, LDL-C, VLDL-C and Al were calculated and FSG, TC, TG, HDL and SUA were measured for the intervention group. All data were presented as means \pm standard deviation (SD) of mean. Independed $t-$ test of two mean was used. Dependent $t$ - test of two mean was applied for the differences in the intervention group (before and after). Chi square test of independence was used for categorial variables. Pvalue $\leq 0.05$ was considered statistically significant.

Results: Initially, at the start of the study, there was insignificant difference between the interventions and the control groups with regard age, sex, weight, BMI, systolic and diastolic BP, serum TC, HDL- C, LDL $-C$, Al and SUA, with a significant differences in FSG, TG, and VLDL. By comparison before and after supplementation in the intervention groups, there was a significant decrease in the systolic and diastolic BP record, FSG, TC, TG, LDL -C, AI, SUA, with a significant increase in body weight and HDL -C.

Conclusion: Bee propolis supplementation at a dose of $500 \mathrm{mg}$ twice daily for 2 months carries a beneficial effects on BP record, FSG, lipid profile, and SUA, which should be taken in preventive medicine, since hyperglycemia, hyperlipidemia and hyperureciemia, contributed to the development of atherosclerosis, cardiovascular and cerebrovascular diseases.

Keywords: Propolis, healthy volunteers, FBS, lipid profile, uric acid, blood pressure.

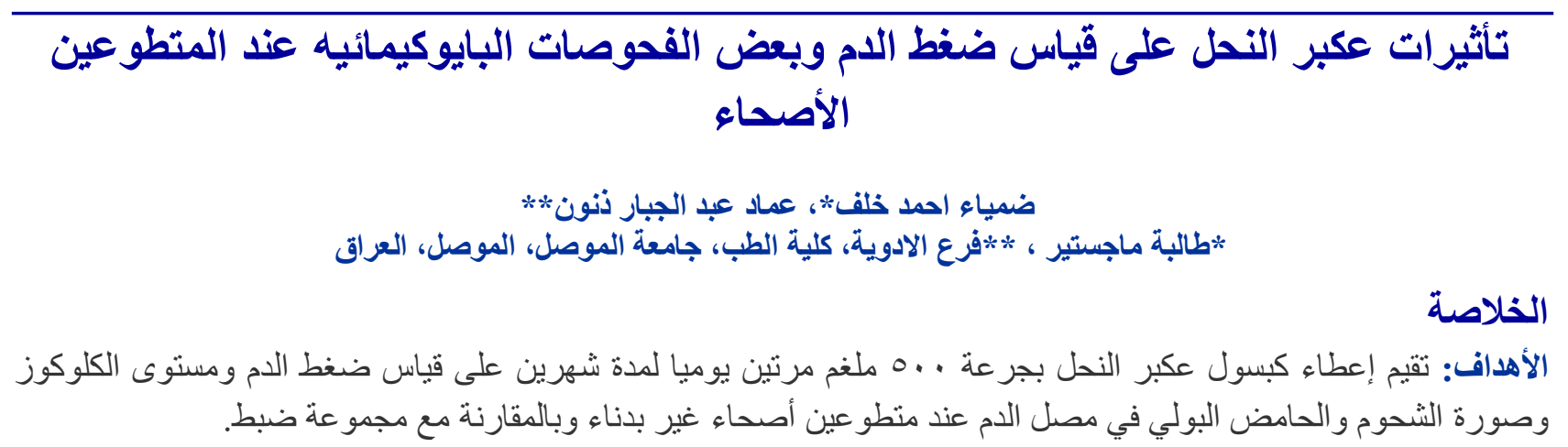




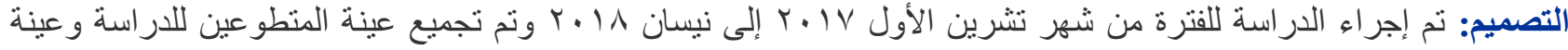

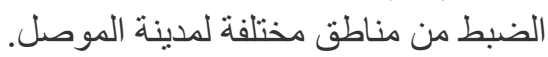

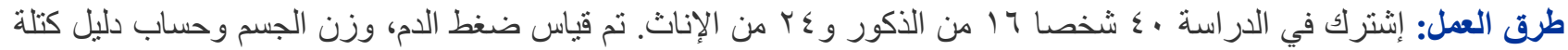

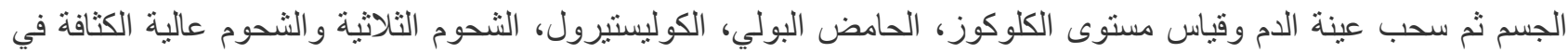

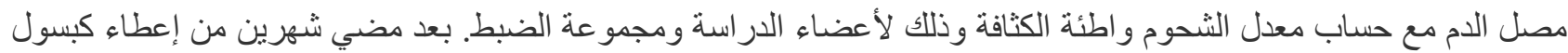

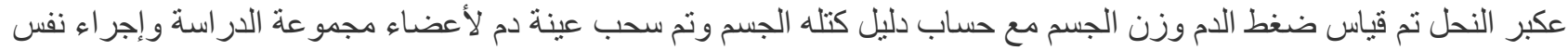
الفحوصات المذكورة أعلاه.

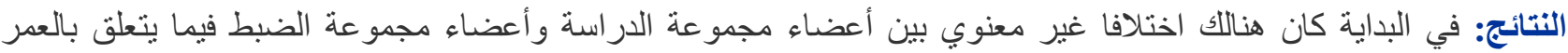

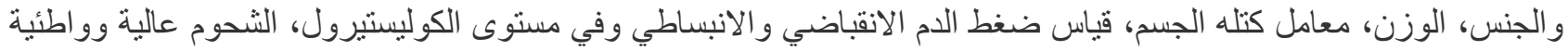

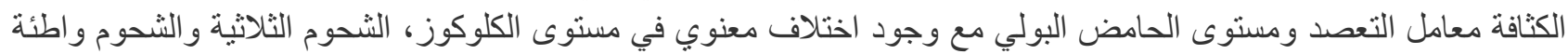

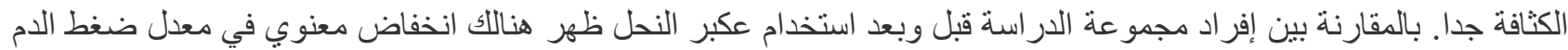

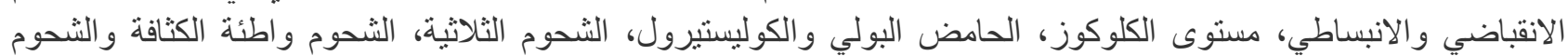

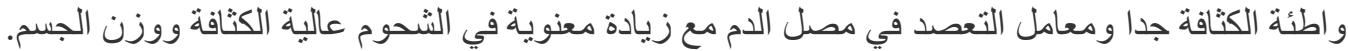

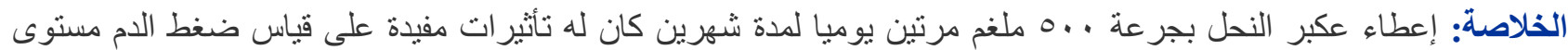

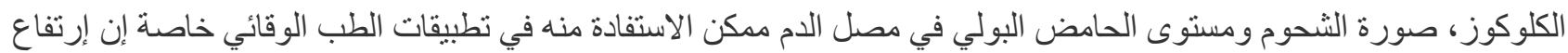

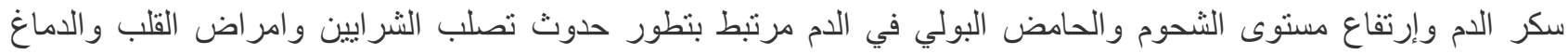
الو عائية. كلمات المفتاح: عكبر النحل، متطوعين أصحاء، مستوى الكلوكوز في حالة الصيام، صورة الثحوم، الحامض البولي وضغط الدم.

\section{INTRODUCTION}

$\mathrm{n}$ modern primary care, doctors spend considerable time and effort, concentrating on preventive medicine practice. ${ }^{1}$ Hyperglycemia, hyperlipidemia and hyperureciemia were considered as main risk factor for developing atherosclerosis and cardiovascular diseases. ${ }^{2,3,4}$ Type II diabetes mellitus (DM) is associated with 4 folds increased risk of both coronary and cerebrovascular disease ${ }^{2}$ and atherogenic dyslipidemia characterized by abnormal changes in plasma lipid profile as low $\mathrm{HDL}-\mathrm{C}$ and increased $\mathrm{TG}^{3}$ and only recently the pathophysiological links between elevated SUA concentration and the risk for atherosclerotic cardiovascular and cerebrovascular disease become clear. ${ }^{4}$

Currently word attention were directed to traditional medicine. ${ }^{5}$ Propolis is a resinous material, containing a variety of substances and is used in cosmetics, food supplement and in medicine for centuries in various health problems as treatment and prevention. It exhibit abroad spectrum activities including antibacterial, ${ }^{6}$ antifungal, ${ }^{7} \quad$ antiviral, ${ }^{8} \quad$ anti-inflammatory, ${ }^{9}$ antioxidant, $^{10}$ immunostimulating $^{11}$ and cytostatic proprieties. $^{12}$

In this study we evaluated the preventive effect of encapsulated bee propolis as daily supplement of $500 \mathrm{mg}$ twice daily for 2 months on BP record, FSG, lipid profile, SUA in otherwise non-obese healthy volunteer in comparison to the controls.

\section{SUBJECTS AND METHODS}

Forty otherwise healthy non-obese volunteer (sixteen male and 24 female) were included in the study that was conducted from October 2017 to April 2018. Pregnant and lactating women, those with history of allergy, asthma and bleeding disorders were excluded.

Also included in the study 43, age, sex and body weight matched healthy subjects as a control group.

Initially, for both the members of intervention and control groups, BP were recorded, body weight measured, BMI was calculated using following equation:

$\mathrm{BMI}=$ Weight $(\mathrm{Kg}) /$ Height $(\mathrm{m} 2)^{13}$

FSG, TC, TG and HDL-C were measured Using kits of Biolabo Company (France). 
LDL $-C$ was calculated using the following equation: ${ }^{14}$

TC - HDL - VLDL -C

VLDL level was calculated by the following equation: ${ }^{14}$

TG/5=VLDL

Atherogenic index calculated as: ${ }^{15}$

A.I $=\mathrm{TC} / \mathrm{HDL}-\mathrm{C}$

Also a kit from Biolabo Company - France was used for measurement of SUA. ${ }^{16,17}$

After 2 months of bee propolis (Forever Company -USA) supplementation in a dose of 500 mg twice daily, BP were recorded, body weight, BMI, LDL-C, VLDL-C and A.I were calculated and serum TC, TG, HDL-C, FSG and SUA were measured.

\section{RESULTS}

As shown in Table 1, the comparison between the intervention and the control groups with regard to personal characteristics, demonstrated insignificant differences.

Before 2 months of bee propolis supplement, there was a significant higher TG. and VLDL $-\mathrm{C}$ concentrationsand lower FSG in the intervention group in comparison to control Table 2.

After 2 months of encapsulated bee propolis supplementation and by comparing the intervention and the control groups, there was a significant differences in systolic and diastolic blood pressure record, FSG , TC . LDL $-\mathrm{C}$ and A.I (Table 3, Table 4).

By comparison before and after supplementation of bee propolis in the intervention group, there was a significant reduction in systolic and diastolic blood pressure (\% of improvement: 8.39), diastolic blood pressure (\% of improvement: $12.42)$ with a significant increase in body weight (1.62 \%) (Table 5).

Also there was a significant reduction in FSG (\% of improvement 10.95), SUA (20.64\%), TC (15.33\%), LDL -C (26.27\%), VLDL -C (34.39\%), TG $(34.47 \%)$ and A.I (34.47\%), with a significant increase in HDL-C (8.18\%) as shown in (Table 6).
Table 1. Comparison between the intervention and control groups with regard personal characteristics.

\begin{tabular}{lccc}
\hline Characteristics & $\begin{array}{c}\text { Intervention } \\
\text { group } \\
{[\mathrm{n}=40]} \\
\text { Mean } \pm \text { SD }\end{array}$ & $\begin{array}{c}\text { Control } \\
\text { group } \\
{[\mathrm{n}=43]} \\
\text { Mean } \pm \text { SD }\end{array}$ & $\begin{array}{c}\text { P- } \\
\text { value* }\end{array}$ \\
\hline Age (years) & $29.9 \pm 11.1$ & $29.5 \pm 10.5$ & 0.872 \\
\hline $\begin{array}{l}\text { Systolic blood } \\
\text { pressure } \\
\text { (mmHg) }\end{array}$ & $116.8 \pm 10.2$ & $113.3 \pm 9.4$ & 0.109 \\
\hline $\begin{array}{l}\text { Diastolic blood } \\
\text { pressure } \\
\text { (mmHg) }\end{array}$ & $76.5 \pm 5.8$ & $73.6 \pm 8.5$ & 0.074 \\
\hline $\begin{array}{l}\text { Weight }(\mathrm{kg}) \\
\text { BMI }\left(\mathrm{kg} / \mathrm{m}^{2}\right)\end{array}$ & $59.8 \pm 10.5$ & $60.7 \pm 9.4$ & 0.662 \\
\hline Gender & $22.39 \pm 2.06$ & $22.35 \pm 1.80$ & 0.923 \\
\hline Male & No. (\%) & No. (\%) & \\
\hline Female & $16(40.00)$ & $16(37.21)$ & $0.794^{* *}$ \\
\hline
\end{tabular}

* Independent T-test of two means was used.

** Chi-square test was used.

Table 2. Comparison between intervention and the control groups with regard to measured biochemical parameters before bee propolis supplementation.

\begin{tabular}{lccc}
\hline Parameters & $\begin{array}{c}\text { Intervention } \\
\text { group [n=40] } \\
\text { Mean } \pm \text { SD }\end{array}$ & $\begin{array}{c}\text { Control } \\
\text { group } \\
\text { [n=43] } \\
\text { Mean } \pm \text { SD }\end{array}$ & P-value* \\
\hline FSG (mg/dl) & $84.9 \pm 13.6$ & $93.3 \pm 14.8$ & 0.009 \\
\hline SUA (mg/dl) & $3.73 \pm 1.36$ & $3.34 \pm 1.14$ & 0.168 \\
\hline $\begin{array}{l}\text { S. cholesterol } \\
(\mathbf{m g} / \mathrm{dl})\end{array}$ & $161.8 \pm 29.6$ & $155.9 \pm 29.5$ & 0.366 \\
\hline HDL (mg/dl) & $55.23 \pm 8.28$ & $57.16 \pm 7.18$ & 0.257 \\
\hline LDL (mg/dl) & $90.2 \pm 28.4$ & $86.9 \pm 26.9$ & 0.592 \\
\hline VLDL (mg/dl) & $16.43 \pm 7.61$ & $11.86 \pm 6.34$ & 0.004 \\
\hline TG (mg/dl) & $82.1 \pm 38.0$ & $59.3 \pm 31.7$ & 0.004 \\
\hline A.l & $2.98 \pm 0.66$ & $2.76 \pm 0.58$ & 0.106 \\
\hline
\end{tabular}

* Independent T-test of two means was used 
Table 3. Comparison between the intervention group after bee propolis supplementation and control groups regarding personal characteristic.

\begin{tabular}{lccc}
\hline \multicolumn{1}{|c}{ Parameters } & $\begin{array}{c}\text { Intervention } \\
\text { group after } \\
\text { 2M. } \\
{[\mathrm{n}=40]} \\
\text { Mean } \pm \text { SD }\end{array}$ & $\begin{array}{c}\text { Control } \\
\text { group } \\
{[\mathrm{n}=43]} \\
\text { Mean } \pm \text { SD }\end{array}$ & $\begin{array}{c}\text { P- } \\
\text { value* }\end{array}$ \\
\hline $\begin{array}{l}\text { Systolic BP } \\
(\mathrm{mmHg})\end{array}$ & $107.0 \pm 9.7$ & $113.3 \pm 9.4$ & 0.004 \\
\hline $\begin{array}{l}\text { Diastolic BP } \\
(\mathrm{mmHg})\end{array}$ & $67.0 \pm 7.6$ & $73.6 \pm 8.5$ & 0.000 \\
\hline Weight $(\mathrm{kg})$ & $60.7 \pm 11.3$ & $60.7 \pm 9.4$ & 0.999 \\
\hline BMI $\left(\mathrm{kg} / \mathrm{m}^{2}\right)$ & $22.68 \pm 2.29$ & $22.35 \pm 1.80$ & 0.467 \\
\hline
\end{tabular}

* Independent T-test of two means was used.
Table 4. Comparison between the intervention group after bee propolis supplementation and control groups regarding measured biochemical parameters.

\begin{tabular}{lccc}
\hline \multicolumn{1}{|c}{ Parameters } & $\begin{array}{c}\text { Intervention } \\
\text { group after } \\
\text { 2M. } \\
\text { Mean } \pm \text { S }]\end{array}$ & $\begin{array}{c}\text { Control } \\
\text { group } \\
{[\mathrm{n}=43]} \\
\text { Mean } \pm \text { SD }\end{array}$ & $\begin{array}{c}\text { P- } \\
\text { value* }\end{array}$ \\
\hline FSG (mg/dl) & $75.6 \pm 10.6$ & $93.3 \pm 14.8$ & 0.000 \\
\hline SUA (mg/dl) & $2.95 \pm 1.10$ & $3.34 \pm 1.14$ & 0.117 \\
\hline $\begin{array}{l}\text { S. cholesterol } \\
\text { (mg/dl) }\end{array}$ & $137.0 \pm 32.2$ & $155.9 \pm 29.5$ & 0.006 \\
\hline HDL (mg/dl) & $59.73 \pm 10.24$ & $57.16 \pm 7.18$ & 0.188 \\
\hline LDL (mg/dl) & $66.5 \pm 31.1$ & $86.9 \pm 26.9$ & 0.002 \\
\hline VLDL (mg/dl) & $10.78 \pm 6.73$ & $11.86 \pm 6.34$ & 0.453 \\
\hline TG (mg/dl) & $53.9 \pm 33.6$ & $59.3 \pm 31.7$ & 0.452 \\
\hline A.l & $2.34 \pm 0.62$ & $2.76 \pm 0.58$ & 0.002 \\
\hline${ }^{*}$ Independent T-test of two means was used. &
\end{tabular}

Table 5. Comparison between the pre and post- supplementation of bee propolis in the intervention group regarding personal characteristics.

\begin{tabular}{lccccc}
\hline \multicolumn{1}{c}{ Parameters } & $\begin{array}{c}\text { Base line } \\
\text { Mean } \pm \text { SD }\end{array}$ & $\begin{array}{c}\text { After } 2 \text { months } \\
\text { Mean } \pm \text { SD }\end{array}$ & Before - after & $\begin{array}{c}\text { \% } \\
\text { improvement } \\
\text { rate }\end{array}$ & P-value \\
\hline $\begin{array}{l}\text { Systolic BP } \\
(\mathrm{mmHg})\end{array}$ & $116.8 \pm 10.2$ & $107.0 \pm 9.7$ & $9.8 \pm 1.31$ & 8.39 & 0.000 \\
$\begin{array}{l}\text { Diastolic BP } \\
(\mathrm{mmHg})\end{array}$ & $76.5 \pm 5.8$ & $67.0 \pm 7.6$ & $9.50 \pm 6.77$ & 12.42 & 0.000 \\
Weight $(\mathrm{kg})$ & $59.8 \pm 10.5$ & $60.7 \pm 11.3$ & $-0.97 \pm 2.04$ & 1.62 & 0.005 \\
\hline BMI $\left(\mathrm{kg} / \mathrm{m}^{2}\right)$ & $22.39 \pm 2.06$ & $22.68 \pm 2.29$ & $-0.29 \pm 0.17$ & 1.30 & 0.092 \\
\hline${ }^{*}$ Paired T-test of two means & & & & & \\
\hline
\end{tabular}

Table 6. Comparison between the pre and post- supplementation of bee propolis in the intervention group regarding measured biochemical parameters.

\begin{tabular}{lccccc}
\hline \multicolumn{1}{c}{ Parameters } & $\begin{array}{c}\text { Base line } \\
\text { Mean } \pm \text { SD }\end{array}$ & $\begin{array}{c}\text { After } 2 \text { months } \\
\text { Mean } \pm \text { SD }\end{array}$ & Before - after & $\begin{array}{c}\text { \% improvement } \\
\text { rate }\end{array}$ & P-value* $^{*}$ \\
\hline FSG (mg/dl) & $84.9 \pm 13.6$ & $75.6 \pm 10.6$ & $9.3 \pm 13.0$ & 10.95 & 0.000 \\
SUA (mg/dl) & $3.73 \pm 1.36$ & $2.95 \pm 1.10$ & $0.77 \pm 0.82$ & 20.64 & 0.000 \\
S. cholesterol & $161.8 \pm 29.6$ & $137.0 \pm 32.2$ & $24.8 \pm 28.1$ & 15.33 & 0.000 \\
(mg/dl) & $55.23 \pm 8.28$ & $59.73 \pm 10.24$ & $-4.50 \pm 7.91$ & 8.15 & 0.001 \\
HDL (mg/dl) & $90.2 \pm 28.4$ & $66.5 \pm 31.1$ & $23.7 \pm 28.3$ & 26.27 & 0.000 \\
LDL (mg/dl) & $16.43 \pm 7.61$ & $10.78 \pm 6.73$ & $5.65 \pm 5.59$ & 34.39 & 0.000 \\
VLDL (mg/dl) & $82.1 \pm 38.0$ & $53.9 \pm 33.6$ & $28.3 \pm 27.92$ & 34.47 & 0.000 \\
\hline TG (mg/dl) & $2.98 \pm 0.66$ & $2.34 \pm 0.62$ & $0.64 \pm 0.65$ & 21.48 & 0.000 \\
\hline A.I & & &
\end{tabular}

* Paired T-test of two means was used. 


\section{DISCUSSION}

Propolis is a safe natural resinous product, made by bees from material extracted from plants, flowers and bees wax. It is regarded as a folk medicine possessing a broad spectrum of biological activities including hypoglycemic activity. ${ }^{18}$

This study revealed a significant weight gain in the intervension group after 2 months of bee propolis supplementation at a doses $500 \mathrm{mg}$ twice daily. This is in agreement with study conducted by Denli et al, $2005^{19}$, whom reported that the addition of propolis in the diet significantly increase the growth parameter of quail chicks such as body weight gain and feed consumption and improvement feed efficacy compared with controls and they suggested that it could be due to antimicrobial activity of the propolis extract that resulted in improvement of intestinal hygiene that lead to improved digestion and absorption, beside that it has been suggested that bee propolis contain protein, amino acids, vitamins, and flavonoids, for this resinous it has been used by some people as a nutritional supplement. ${ }^{20}$

Also on line with our results, the study conducted by albushabaa $(2014)^{21}$, she reported that propolis extract has antihyperglycemic effect and significantly improved the body weight of diabetic rabbits. Yucel et al, (2012) ${ }^{2}$, studied the effect of propolis administration on assessement of growth and neonatal diarrhea in calves, they found an improved live weight gain and growth this attributing to the the activity of propolis against many bacterial pathogens, thus preventing calves diarrhea.

Concerning the effect of propolis on blood pressure record, although all of our subject in the study were normotensive, propolis supplement causes a significant reduction in the mean systolic and diastolic blood pressure in comparison to prepropolis supplementation period and the controls. This is similar to the results of Gogebaken et al., $2012^{23}$, whom concluded that propolis decrease tyrosine hydroxylase, which is the rate limiting enzyme in the biosynthesis of catecholamine in nitric oxide inhibited hypertensive rats.

Talas et al, $2013^{24}$ also reported that propolis might be used to protect against the hypertensive effect of nitro $L-$ arginine methyl ester by increasing the generation of vascular nitric oxide.
Concerning the effect of propolis on biochemical parameters under study, this study reported a significant beneficial effects on FSG, lipid profile indices and SUA. This is in agreement with $\mathrm{Li}$ et al, $2011^{25}$ whom reported that encapsulated propolis can suppress the heightening of FBS in type II diabetic rats, 8 weeks after starting therapy and concluded that encapsulated propolis can improve the insulin sensitivity in type II diabetic rats.

Fuliang et al, (2005) ${ }^{26}$ also reported that propolis lower FSG and lipids leading to deceased out puts of lipid peroxidation and scavenge the free radicals in rats with diabetes mellitus. Bankova $(2005)^{27}$, attributed the hypoglycemic effect of propolis to its flavonoids content. Again our findings were in accordance with study conducted by Zaahkouk et al, $(2016)^{28}$ reporting a significant lower FSG level and increase in plasma insulin level in streptozotocin induced diabetic rats. Lastly and in a human study conducted by Zhao et al $(2016)^{29}$ reported that a Brazilian propolis significantly improved FSG level and plasma insulin in human subjects with type II DM.

In contrast to our study finding, Bulalo et al, $(2009)^{30}$ reported that propolis had no effects on plasma glycemic control and lipid metabolism in diabetic rat model fed on propolis for 28 days, also in contrast to our findings the study conducted by fukuda et al, (2015) ${ }^{31}$ they concluded that 8 weeks supplementation of Brazillian propolis did not have beneficial effect on serum FSG, although it prevented the action of hyperureciemia and dysfunction of renal glomerular filtrating function that commonly developed in patient suffering from DM.

With regard to lipid profile, Albokhadaim $(2015)^{32}$, reported that dietary supplementation of propolis induces a beneficial hypolipidemic effect as hypocholesterlomic and hypotriglyceridemic effect in the sera of rat fed on high cholesterol diet. The effect on serum cholesterol could be attributed to inhibition of 3-hydroxy-3-methyl-glutarylcoenzyme A (HMG - COA) reductase, the rate limiting enzyme that mediates the first step in cholesterol biosynthesis, while the effect on TG might be attributed to lipase stimulation.

Also in line with our findings, the study conducted by EL-Sayed et al, (2009). ${ }^{33}$ They conducted that propolis extract offers promising 
antidabetic and hypolipidemic effects that might be mainly attributed to its potent antioxidant property.

With regard to effect on SUA, our study reported a significant reduction in SUA after 2 month supplementation of bee propolis, this is in line with the study conducted by Omnia et al, (2014) ${ }^{34}$, and concluded that propolis act as a protective agent against thioacetamide-induced hyperammonemia in rats and that bee propolis and bee pollen significantly reduces SUA.

In a recent research work Amin et al, $(2017)^{35}$, studied the reno protective and antioxidant effect of silymarine and propolis on diclofenac sodium induced renal toxicity in rats and concluded that propolis with pollen provide a natural protection against renal toxicity induced by diclofenac sodium and both resulted in a significant decrease in urea, creatinine and SUA level as compared to the group receiving diclofenac only.

In conclusion: Encapsulated propolis supplement for 2 months at dose of $500 \mathrm{mg}$ twice daily in otherwise healthy volunteer, resulted in a beneficial effect on blood pressure record, FSG, lipid profile and serum uric acid which might through a light on the protective effect of propolis against atherosclerosis and cardiovascular diseases in a primary care preventive medicine practice.

\section{REFERENCES}

1. Sniplesky D, Careker K, Sundsted K, Burton MC. Primary care physicians practicing preventive medicine in out patient setting. International Journal Preventive Medicine $2016 ; 7: 5$.

2. Nathan DM, Cleary PA, Backlund JY, Genuth SM, Lachin JM, Orchard TJ et al. Diabetes control and complication trial/epidemiology of diabetes interventions and complication (DCCT / EDIC) study research group. intensive diabetes treatment and cardiovasculare diseases in patient with type I diabetes New England Journal of Medicine. 2005; 353 (25) : 2643 -53.

3. Nelson $\mathrm{RH}$. Hyperlipidemia as arisk factor for cardiovascular disease. Primary Care. 2013 march; 40 (1) : 195- 211.

4. Krishnan E, Pandya BJ, Chung L, dabbous O. Hyperurecemia and the risk for subclinical coronary atherosclosis. data from a prospective observational cohort study. Arthritis Research and Therapy 2011.13 :R 66 .

5. Cordell GA, C olvard MD. Natural product and tradional medicine : turning on a paradigm. Journal National product. $2012 ; 75$ (3) : pp $514-525$.

6. Urgur A, Arslan T. An in vitr study on antimicrobial activity of propolis from mugla province of turkey. Journal of Medicinal Food 2004; 7( 1$): 90-4$.
7. Ota C, U nterkir cher C, Fantinato V, Shimizu MT Antifungal activity of propolis on different species of candida. Mycoses 2011;44 (9-10) : 375 - 378.

8. Amaros M, $S$ imoes CMO, Gre $L$, saurvager $F$, Cormier M . Comparison of the antiherpes simplex virus activities of propolis and 3 mthyl -butyl - 2- enyl caffeate. Journal National Product 1994; 57: 644- 647. 9. Miyataka $H$, Nishiki $M$, Matsumoto $H$, Fujimoto $T$, Matsuka M, Satoh T. Evaluation of propolis. Evaluation of brazilian and chinese propolis by enzymatic and physico-chemical methods. Biological and Pharmaceutical Bulletine 1997 ; 20: 496-56.

10. Nagai $T$, Inouse $R$, Inouse $H$, Suzuki N. Preparation and antioxidant properties of water extract of propolis. Food Chemistry 2003 .80: 29-33.

11. Dimov V, Ivanovska N, Manolova, Bankova V, Nikolov N, Popov S. Immunomodulatory action of propolis. influncing on anti-infectious protection and macrophage function. Apidology $1991 ; 22$ : 155-162.

12. Banskota AH, Tezuka $Y$, Midorikawa $K$, Matsushige $\mathrm{K}$, kadota $\mathrm{S}$. Two novel cytotoxic benzofuran derivative from Brazilian propolis. Journal National product 2000; 63 (9) : 1277- 1279.

13. Blak barn $H$, Jacobs $D$. Commentary origins and evaluation of body mass idex (BMI) continuing saga. Interntional Journal of Epidemioloy $2014 ; 43(3)$ :665 669 .

14. Friedewald W T, Levy R I, Fredrickson D S."Estimation of the concentration of low-density lipoprotein cholesterol in plasma, without use of the preparative ultracentrifuge,"Clinical Chemistry, 1972. 18. (6). 499-502.

15. Castelli W.P, Abbott R.D, McNamara PM. Summary estimated of cholesterol used to predict coronary heart disease . Circulation ,67(4):730-734(1983).

16. Burtis C.A, Ashwood E.R, Saunders W.B, Tietz N.W Text book of clinical chemistry, $3^{\text {rd }}$ Edition. (1999). pp. 1245-1250.

17. Fossati $P$, Prencipe $L$, and Berti G. Use of 3.5dichloro-2- Hydroxybenzene sulfonic acid / 4 Amino phenazone chromogenic system in direct enzymatic assays of uric acid in serum and urine. Clinical Chemistry.: 26(227-231) 1980.

18. Abo-Salem OM, El-del RH, Harison G.E.I EL Halawany N, Ghoraim MM. Expermintal diabetic nephropathy can be prevented by propolis effect on metabolic disturbances and renal oxidative parameter. Pakistan Journal of Pharmaceutical Sciences $2009 ; 22$ (2) : pp $205-201$.

19. Denli M, Cankaya S, Silici1 S, Okan F, Uluocak A N. Effect of Dietary Addition of Turkish Propolis on the Growth Performance, Carcass Characteristics and Serum Variables of Quail (Coturnix coturnix japonica). Ascian-Australasian Journal of Animal Sciences. 2005;18, ( 6) : 848-854.

20. Lee SW, Kim HJ, Hwangbo S. Studies on the chemical characteristic of Korean propolis. Korean Journal Society for Food Science of Animal Resources $2001 ; 21: 383-388$.

21. Albushabaa $\mathrm{SHH}$. Effect of propolis on blood glycemic control and lipid metabolism in diadetic rabbits. International Journal of Sciences and Engineering Research 2014 .5(12):800-807. 
22. Yucel B, Onenc A, Kaya A, Altan O. Effect of propolis on growth performance and neonatal diarrhea of calves. Symbiosis Journal of Veterinary Sciences 2015; $1(1): 1-5$.

23. Gogebakan A, Talas ZS, Ozdemir I and Sahna E Role of propolis on tyrosine hydroxylase activity and blood pressure in nitric oxide synthase-inhibited hypertensive rats. Clinical and Experimental Hypertension, 2012. 34(6): 424- 428.

24. Talas ZS, Gogebakan A, Onen I. Effect of propolis on blood biochemical and heamaological parameter in nitric oxide synthase inhibited rats by nitro $-\mathrm{L}-$ arginine methyl ester. Pakistan Journal of Pharmaceutical Sciences. 2013; 26(5): pp 915-919.

25. Li Y, Chen M, Xuan H, Hu F. Effects of encapsulated propolis on blood glycemic control, lipid metabolism and insulin resistance in type 2 diabetes mellitus rats. Evidence-Base Complementary and Alternative Medicine 2011; 2012 :pp(1-8).

26. Fuliang HU, Hepburn HR, Xuan $H$,Chen M, Daya S, Radloff SE. Effects of propolis on blood glucose, blood lipid and free radicals in rats with Diabetes mellitus. Pharmacological Research, 2005.51, 147-52.

27. Bankova V .Chemical diversity of propolis and the problem of standardization. Journal of Ethnopharmacology 2005.100(1-2): 114-117.

28. Zaahkouk SAM, Ibrahim DF, Elarabi BE. Antioxidant and hypoglycemic studies on Egyptian propolis and foeniculum vulgare on alloxan induced diabetic rats. International Journal of Animal Biology 2016 ;2:pp1-10. 29. Zhao L, Pu L, Jingyu $W$, Jinghua $L$, Jianguan $W$, Zhonghao $\mathrm{X}$, et al. Brazilian green propolis improves antioxidant function in patient with type 2 diabetes mellitus. International Journal of Environment and Public Health.2016;14:pp498-507.
30. Bufalo MC, Barreiro DP, Sartori DRS, Sforcin JM. Absences of propolis effect on plasma glycemic control and lipid metabolism in a diabetic rat model. Journal of Apiprodct and Apimedical Science 2009;1(2) ;pp 51-55. 31. Fukuda T, Fukui M, Tanaka M, Senmaru T, Iwase H, Yamazaki $\mathrm{M}$, et al. Effect of brazilian green propolis in patient with type 2 diabetes: A double -blind randomized placebo-controlled study. Biochemical Report 2015;3:pp 355-360.

32. Albokhadam I. Influence of dietary supplementation of proplis on hematology, biochemistry and lipid profile of rats fed high cholesterol diet. Journal of Advance Veterinary Animal Research. $2015 ; 2(1)$ :pp 56-63.

33. El-Sayed el-SM, Abo-Salem OM, Aly HA, Mansour AM. Potential anti diabetic and hypolipidemic effect of propolis extract in streptozotocin- induced diabetic rats. Pakistan Journal of Pharmaceutical Sciences 2009; 22(2) : pp 168-174.

34. Omnia MA, Nabila AM, Nada RR. Biochemical effect of propolis and bee pollen in experimentally - induced hyperammonemia in rats. Benha Veterinary Medical Journal $2014 ; 27(1)$ :pp 8-28.

35. Amin KA, Ahmed RR, Hozayen WG, Antar A. Renoprotective and antioxidant effect of silymarin and propolis on diclofenac sodium induced renal toxicity in rats. International Journal of Pure and Applied Biosciences 2017;5 (2):pp 31-42. 